\title{
A systematic review to appraise the evidence relating to the impact and effects of formal continuing profe- ssional education on professional practice
}

\author{
Helen Sykes, Jenny Temple \\ Faculty of Health, Education and Society, Plymouth University. \\ Correspondence: Jenny Temple. Address: Apartment 6 White Gables, Rawlyn Road, Chelston, Torquay Devon \\ TQ26PQ, England. Telephone: 07-815-527-976. Email: jtemple@plymouth.ac.uk
}

Received: January 9, 2012

DOI : $10.5430 /$ jnep.v2n4p194
Accepted: March 26, 2012

Published: November 1, 2012

URL: http://dx.doi.org/10.5430/jnep.v2n4p194

\section{Abstract}

The literature relating to post-registration education showed that registered nurses demand higher education in order to keep up with pre-registrants. The systematic review of the literature also suggested that registered nurses undertake higher education for personal reward but that it may have no direct benefit to patient care. This review was undertaken as part of an MSc in Health and Social Care Education. The review included 21 papers on registered nurses who had completed individual modules and full educational pathways, but did not consider mandatory study sessions or pre-registration programmes.

Each article was critically appraised, data was extracted, tabulated, and synthesised using a narrative synthesis approach. The findings showed that diploma level students (those obtaining a qualification at an academic level equivalent to the 2nd year of a degree programme, but already professionally registered) acquired more knowledge during their studies. They were able to transpose them into practical skills and enhance the skills required for registration; but the literature also shows that these changes could not be maintained, due to other influences. Students of Bachelors and Masters Education developed academically and professionally, and whilst these effects advance more gradually, they are apparent long-term. All registered nurses, regardless of the level of academic study, met a number of barriers to implementing newfound knowledge and skills; and managerial constraints were found to be the most prominent.

Overall findings indicate that post-registration higher education undertaken by nurses does positively influence professional practice.

\section{Key words}

Post-registration, Education, Health care, Practice

\section{Introduction}

UK governmental policy is constantly changing in response to healthcare targets, along with the evolving needs of society, meaning that healthcare practice also has to change. Therefore, for a long time there has been emphasis on the need for registered nurses to continually develop beyond pre-registration education ${ }^{[1]}$. Continuing professional education (CPE) is 
a branch of continuing professional development (CPD), and two separate terms. However, CPD and CPE are sometimes incorrectly interchanged ${ }^{[2]}$.

Continuing Professional Development (CPD) is a structured process through which registered nurses maintain competence, and advance personal qualities, professional knowledge, and skills ${ }^{[3]}$. Whilst CPD is strategically used to aid staff recruitment and retention through acknowledging their value, the goal is to ensure effective, evidence-based care is delivered safely and competently ${ }^{[4]}$. CPD provides the scope for education and learning to occur from a range of activity ${ }^{[5]}$.

CPE involves formal post-registration education obtained through accredited University courses, which registered nurses consider most relevant to professional practice and development ${ }^{[2]}$. For the purpose of this review, the authors interpret $\mathrm{CPE}$ as post-registration education, and the terms continuing professional education and post-registration education are interchanged.

In order to understand why registered nurses consider CPE more pertinent to their practice, a preparatory simple literature search was conducted. Databases such as Cumulative Index of Nursing and Allied Health Literature (CINAHL), British Nursing Index (BNI), Swetswise, Ovid and PubMed were searched using the terms continuing professional education, post-registration education, continuing professional development, lifelong learning and motivations. Collectively, the literature from the preparatory search highlighted four concepts, the history of nurse education, the principle of CPD, the cost of CPE, and motivations for undertaking CPD and CPE. These four principles provide the contextual background and rationale for this review, from which it was evident that a systematic review was required.

Nursing education has changed dramatically over the years, with the most radical change being the evolution from apprentice-style pre-registration training to higher education ${ }^{[6]}$. The opportunity for nurses to study at higher education institutions (HEIs) has existed since the 1960's. Yet, most nurses trained through the traditional apprentice-style way ${ }^{[7]}$, where student nurses were employed as part of the workforce, and learned "on the job” ${ }^{[8]}$. Students were sources of cheap labour but the service need was foremost and often took precedent over learning ${ }^{[9]}$. There were concerns that the apprentice-style student nurses would not produce autonomous practitioners, who could meet the demands of the modern National Health Service (NHS). Therefore, in 1989, the HEI based Project 2000 was implemented in the UK, which allowed student nurses to study to diploma or degree level, whilst simultaneously gaining their professional registration.

Project 2000 excluded student nurses from the workforce where their student status was recognised through being "supernumery" ${ }^{[10]}$. A supernumery status meant that during practice placements students were no longer apprentices and were additional to the workforce numbers. Nurse education within HEIs enhanced learning opportunities and practice development, by facilitating reflection and the sharing of learning and experience ${ }^{[11]}$, knowledge acquisition, and research opportunities ${ }^{[12]}$. Higher education also produces analytical thinkers, good decision-makers, and leaders ${ }^{[13]}$.

However, nurse education within HEIs was not without criticism. The practical nature of the old apprentice-style education had the benefit of newly qualified nurses immediately becoming orientated to the practice world ${ }^{[9]}$. Nurse education within HEIs was considered theoretical, so nurses educated there would be "thinkers", not "doers", with little ability to meet the practical skills demanded of care delivery ${ }^{[9]}$. Therefore, practice placements would provide students with clinical experience and facilitate their competence through the application of theory ${ }^{[8,14]}$.

The move of nurse education into HEIs saw registered nurses become more engaged in pre-registration learning by mentoring students' during their clinical placements ${ }^{[6]}$. Registered nurses feared they would be unable to mentor students if their own educational level was unequal to pre-registrants ${ }^{[8]}$. Registered nurses, trained through the apprenticeship style also feared being academically inferior to diploma or graduate nurses, since the value of their knowledge acquired experientially was not always recognised ${ }^{[13,15]}$. Therefore, the demands for CPE increased because registered nurses pursued higher education qualifications through a part-time modular process. Since the evolution of nurse education into 
HEIs, the academic and professional status of nursing has gradually gained impetus. The Department of Health (DH) have stated that all pre-registrants will follow a degree programme ${ }^{[16]}$ if they commence nurse education on or after 2013. This will spiral registered nurses' demand for CPE in an attempt to stay a step ahead of pre-registrants ${ }^{[13]}$.

CPD, in the form of Post-Registration Education and Practice (PREP), became mandatory for UK registered nurses in 1998. Nurses must achieve a minimum of 35 hours learning activity over three years to qualify for re-registration ${ }^{[17]}$. CPD and PREP do not include education of statutory topics such as manual handling and fire safety. These knowledge areas are essential for staff and patient safety, but are categorised as mandatory training. All Trusts must provide mandatory training and all employees must attend ${ }^{[17]}$; which Bahn ${ }^{[18]}$ describes as employer's self-protection against litigation.

Registered nurses need to view CPD as a natural undertaking that is part of life-long learning, and which influences their practice through the transference of evidence. However, the advent of mandatory CPD and PREP has contributed to the demand for higher education qualifications ${ }^{[2]}$. Continuing Professional Education in the context of this review is acquired from higher education and is 'supplied' by managers and organisations, so it has a cost. Powell ${ }^{[19]}$ recognises that the never-ending demand for CPE forces managers to juggle limited study opportunities with maintaining a safe and effective work environment. As a result, study opportunities are often "ad hoc" because the necessity to fulfill PREP standards competes with CPE and the statutory demands of mandatory training ${ }^{[20]}$. In the light of financial constraints, organisations are cutting training budgets so it is imperative that employers are satisfied that CPE results in patient care improvement ${ }^{[21]}$.

Some researchers claim registered nurses are motivated to seek CPE for personal gain and in order to improve the chances of promotion and career advancement ${ }^{[22-24]}$. It is also apparent that only when in positions of authority can nurses readily influence practice changes which are evidence-based ${ }^{[22]}$. However, Hughes ${ }^{[25]}$ found some nurses believed having higher education qualifications made no difference to their practice or ability to influence others.

Whilst perceived barriers to undertaking CPE were noted as personal constraints, family commitments, lack of funding, unsupportive managers, and work environments, registered nurses were found to be positive towards CPE. Registered nurses are motivated to pursue higher education because it enhances practice, and facilitates holistic, evidence-based care; from which patients reap the benefit ${ }^{[9,26-29]}$. However, nurses do not automatically transpose the academic skills of higher education into clinical performance ${ }^{[19,22,24,25,30,31]}$, which raises questions about the benefits of CPE on patient care.

\section{Aim}

The aim of this systematic review was to appraise and synthesise the evidence relating to continuing professional education in order to answer the research question "what are the impact and effects of continuing professional education on the professional practice and development of registered nurses". In order to answer this question, the following objectives were undertaken.

- To scrutinise the data of primary studies where post-registration higher education was investigated, and determine the validity and reliability of the evidence.

- To identify the knowledge, skills, behaviours, and/or attitudes that registered nurses acquire as a result of undertaking post-registration higher education.

- To establish how registered nurses apply knowledge, skills, behaviours and/or attitudes to practice following post-registration higher education. 


\section{Methods}

Systematic reviews are secondary evidence and enable researchers to make conclusions by synthesising the best available primary evidence ${ }^{[32]}$. In order to meet the same standards as primary evidence, researchers of systematic reviews follow protocols to demonstrate the explicit methods they use within the review ${ }^{[33]}$. A protocol demonstrates transparency, helps eliminate bias and enables a study to be replicated ${ }^{[32]}$. However, according to Sandelowski ${ }^{[32]}$, there will always be an element of subjectivity because different researchers will use different methods, and therefore, the framework is the only protocol element that allows replication. No particular framework is advocated and the researcher of this review adapted a framework from Greenhalgh ${ }^{[34]}$.

PICO is an acronym of the four elements needed to define a research question: population, intervention or interest, comparators or context and outcomes ${ }^{[35]}$. In order to define the research question, the researcher utilised the PICO framework, which had the advantage of forcing the researcher to consider the full scope of the question as well as to provide focus and structure for the literature search. Consequently, systematic reviews founded on questions following the PICO structure are more effective than those reviews that do not follow this framework ${ }^{[36]}$.

After applying the PICO framework, the final question became "what are the impact and effects of continuing professional education on the professional practice and development of registered nurses". This question then incorporated the four PICO components; population (nurses), interest (professional practice and development), context (continuing professional education), and outcomes (impact and effects). The research question also aligned to the aim of objectives of the review.

The inclusion criteria were original research since 1986, registered nurses qualifying before Project 2000 or with Project 2000 and subsequently undertaking further HEI studies. Studies were at Diploma, Bachelors or Masters Level, which involved programmes, courses, or isolated modules demonstrating the acquisition of knowledge, skills, behaviours, and attitudes. The researcher considered studies where the focus was CPE in relation to any nurse, their experiences, and perceptions, and had examined the effect of CPE on practice and self-development.

Studies for potential inclusion were located using systematic search strategies. A literature search was undertaken using the PICO framework as a structured guide on which to formulate different search combinations ${ }^{[35]}$. In following the PICO framework, the researcher was enabled to combine the following key words systematically.

Participants: -Registered Practitioners, Registered Nurses, Healthcare Practitioners

Interest: -Continuing professional development, Continuing education, Continuing professional education, Professional practice, Lifelong learning, Evaluation, Perceptions, Motivations and Experiences

Context: -Post-registration, Post-graduate, Undergraduate, Higher education, Diploma, Degrees, Masters and $\mathrm{PhD}$

Outcomes: -Benefits, Impacts, Effects and Development

The researcher applied the search terms, to a number of health and education databases, using a number of different search strategies. To ensure all possible combinations, and to avoid duplication, notes were made each time a specific combination was used ${ }^{[37]}$. The search, therefore, facilitated a pilot of the inclusion criteria to determine their accuracy and sensitivity and to avoid selection bias ${ }^{[36,38]}$.

Following the electronic search, 168,368 citations were identified. All citations were "sifted" through a staged process by applying the inclusion criteria to title, abstract and full text to determine eligibility within the review ${ }^{\text {[39] }}$.

Despite the search of the electronic databases identifying a number of studies, it was possible that not all potential evidence was retrieved. This is common where "witty" titles do not portray the study under discussion ${ }^{[37]}$. Therefore, the researcher 
thoroughly read the reference lists of those studies, which were downloaded as full text articles, if they were considered for inclusion during the sifting stage ${ }^{[40]}$. On reading the reference lists, 32 citations in addition to the original 168,368 were located, which demonstrates the value of not relying on electronic searching.

Electronic journals dedicated to health education were also searched because it was possible these journals were not captured within the health and education databases searched. Eventually using all possible search combinations, it became apparent that the search was exhaustive as no new references were obtained.

With the larger number of citations obtained and the warning by Fink ${ }^{[38]}$ that internet searches can yield information of questionable quality, an additional internet search was not pursued. The researcher did not locate any unpublished research ${ }^{[41]}$, and due to time constraints this could not be pursued ${ }^{[35]}$ and neither were published dissertations and thesis searched for. The researcher acknowledges these decisions do not truly conform to the conventional systematic review, where the aim is to include all relevant evidence. However, it is acceptable not to retrieve all data, and the data subsequently becomes a sampling frame ${ }^{[42]}$.

Following the search, the number of studies for potential inclusion was 25 and these had been located from various databases. Following the selection process, the researcher devised a preliminary data extraction tool to facilitate early recording of validity and key findings, as well as to verify inclusion decisions ${ }^{[37,41]}$. During this process, it became clear some authors did not report all data collection details, and these were contacted for clarification. Subsequently, one author supplied an additional study not previously located. Following preliminary data extraction, the researcher of this review now deemed the outcomes of some studies irrelevant. Therefore, five studies were excluded. The total number of studies included in this review was therefore 21. To strengthen transparency, Figure 1 summarises the elimination process.

The 21 studies comprised of nine qualitative, eight non-experimental and four mixed-method studies, conducted 1990 to 2009. The studies were predominantly British $(n=17)$, with one American, one Australian and two from Malaysia Borneo. Whilst this reflects the language bias within the databases searched, it may also reflect the interest of the topic within these countries ${ }^{[43]}$. However, it is also possible that this relates to search issues ${ }^{[35,39]}$.

Studies fell into the following categories:

1) Qualitative studies, isolated diploma modules ${ }^{[44,45]}$

2) Qualitative studies, isolated degree modules ${ }^{[46]}$

3) Qualitative studies, completed Bachelors degree programmes ${ }^{[47-50]}$

4) Qualitative studies, completed Masters degree programmes ${ }^{[51,52]}$

5) Non-experimental studies, isolated diploma modules ${ }^{[53,54]}$

6) Non-experimental studies, completed diploma programmes ${ }^{[55]}$

7) Non-experimental studies, completed Bachelors degree programmes ${ }^{[56,57]}$

8) Non-experimental studies, completed Masters degree programmes ${ }^{[58-64]}$

9) Mixed method studies, isolated diploma modules ${ }^{[65-68]}$

10) Mixed method studies, isolated Bachelors degree modules ${ }^{[69]}$.

Some of the publications of Jordan ${ }^{[65]}$ and Jordan and Hughes ${ }^{[66]}$ emanated from the same research and those of Pelletier et al ${ }^{[58-62]}$ were staged reports of a longitudinal study; hence for the purpose of this review, these studies were counted as one each. 


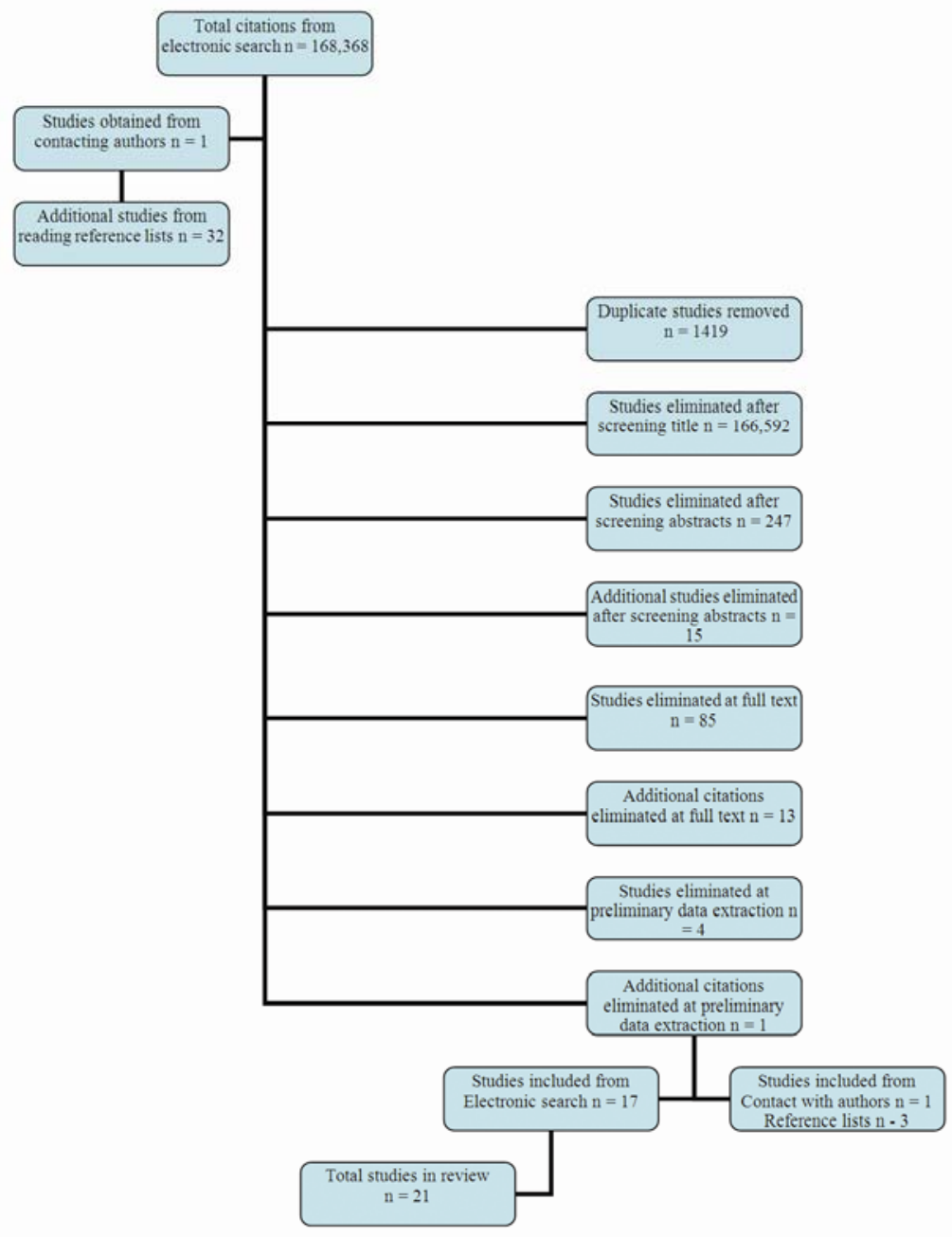

Figure 1. Flowchart of the Elimination Process

\subsection{Critical appraisal \& quality assessment}

Critical appraisal serves different purposes for different researchers, but it enabled the researcher to formulate opinions regarding the quality, flaws, and strengths within the methodologies ${ }^{[70]}$. The researcher decided on the tool devised by National Institute for Clinical Excellence (NICE) ${ }^{[71]}$ for qualitative evidence, and the questionnaire research tool of Greenhalgh ${ }^{[40]}$ for the non-experimental evidence. However, since mixed methods research is still evolving, an appraisal tool for this evidence could not be located ${ }^{[72]}$. Therefore, the researcher adapted a tool from Teddie and Tashakkori ${ }^{[73]}$, who are experienced mixed methods researchers. The mixed methods evidence all had a qualitative dominance, therefore, the researcher also applied the qualitative checklist to see if different judgements were formed ${ }^{\text {[74] }}$.

\subsection{Data extraction, analysis and synthesis}

The researcher customised a data extraction tool ${ }^{[75]}$ and this was piloted to prevent unnecessary data extraction and to enable checks regarding the interpretation of the findings ${ }^{[38]}$. This was possible by comparing the newly extracted findings 
with those preliminarily extracted from the original research interpretation. Studies were classified by their design, and data tabulated to aid in the synthesis stage ${ }^{[40]}$. Additionally, the researcher made notes on methodological strengths and limitations, enabling further validity judgements ${ }^{[76]}$.

Narrative synthesis was deemed the most appropriate tool ${ }^{[77]}$, demonstrating rigour by adherence to the original protocol. Lying between more complex approaches and narrative reviews, it allowed for a deeper level of exploration and interpretation ${ }^{[78,79]}$. To assure validity in the narrative synthesis, the researcher followed the framework recommended by Popay et al ${ }^{[80]}$.

Framework for Narrative Synthesis:

- Developing a theory of how the intervention works, why and for whom

- Developing a preliminary synthesis of findings of included studies

- Exploring relationships in the data

- Assessing the robustness of the synthesis

There is no consensus on the methods for a narrative synthesis ${ }^{[80]}$. However, the researcher needs to explain the heterogeneity (any differences between the studies' reported findings ${ }^{[81]}$ ) within the primary evidence, to ensure that synthesis goes beyond that of traditional reviews ${ }^{[36]}$. This enables juxtaposition of the findings and determines commonalities; the researcher by using tabulation, grouping and clustering, enabled the exploration of relationships, characteristics and findings "within and between" the studies ${ }^{[81,82]}$.

Preliminary synthesis began by reducing and grouping the primary data into an organised and manageable system ${ }^{\text {[83] }}$. Tabulation of this data produced a summarised display of the knowledge, skills, attitudes, behaviours, personal development, and the practice links made by the participants. From these tables, the researcher could explore and compare the findings to identify emerging patterns and themes ${ }^{[84]}$. The final stage of the synthesis was to assess the robustness of the evidence. This involved judging each study to determine the overall weight each study contributed to the review. Overall weight judgements then inform of the overall quality and validity of the review product ${ }^{[80]}$.

The researcher attempted to classify the evidence without criteria, but this highlighted the risk of bias. Bias is a limitation within systematic reviews, as it is introduced by decisions of inclusion and exclusion, and the overall quality of the primary evidence. Therefore, the researcher identified criteria from Hawker et al. ${ }^{[37]}$ and adapted these to the method of Popay et al. ${ }^{[80]}$. The first seven criteria of Hawker et al. ${ }^{[37]}$ relate to trustworthiness, whilst the last two relate to relevance, and for each criterion, a rating scale were applied. To demonstrate validity, the researcher compared each study's overall weight score with the earlier judgements of the appraisal stage ${ }^{[80]}$. These were comparable, which indicated internal validity of the second checklist and consistency within the researcher's assessment.

\section{Results}

The results of the review are presented in relation to each of the three objectives outlined at the beginning of this report.

\section{Objective 1 - To scrutinise the data of primary studies where post-registration higher education was investigated; and to determine the validity and reliability of the evidence.}

Table 1 summarises the methodologies used within each study included in the review. The quality of the original research has also been commented on by the researcher for each study and this can also be seen within table 1 . 
Table 1. Studies included within the Review

\begin{tabular}{|c|c|c|c|c|c|c|c|c|}
\hline Reference & $\begin{array}{l}\text { Quality of } \\
\text { methodology }\end{array}$ & $\begin{array}{l}\text { Sample } \\
\text { size }\end{array}$ & $\begin{array}{l}\text { Data } \\
\text { collection } \\
\text { method }\end{array}$ & $\begin{array}{l}\text { Education } \\
\text { level }\end{array}$ & $\begin{array}{l}\text { Attitudes \& } \\
\text { behaviours }\end{array}$ & $\begin{array}{l}\text { Personal } \\
\text { development }\end{array}$ & $\begin{array}{l}\text { Practice } \\
\text { affected }\end{array}$ & $\begin{array}{l}\text { Barriers to } \\
\text { practice } \\
\text { implementa- } \\
\text { tion noted }\end{array}$ \\
\hline $\begin{array}{l}46 \\
\text { Atkinson } \\
\text { \& Tawse } \\
(2007)\end{array}$ & $\begin{array}{l}\text { purposive } \\
\text { sample, } \\
\text { good minor } \\
\text { flaws }\end{array}$ & 6 & focus group & Diploma & positive changes & yes & yes & \\
\hline $\begin{array}{l}50 \\
\text { Birks et al } \\
(2009)\end{array}$ & $\begin{array}{l}\text { grounded } \\
\text { theory; } \\
\text { fair minor flaws }\end{array}$ & $\begin{array}{l}10 \text { nurses } \\
1 \mathrm{HEI}\end{array}$ & $\begin{array}{l}\text { in-depth } \\
\text { interviews }\end{array}$ & BSc & positive changes & yes & no & \\
\hline $\begin{array}{l}49 \\
\text { Chiu } \\
(2006)\end{array}$ & $\begin{array}{l}\text { purposive } \\
\text { sample; } \\
\text { fair minor flaws }\end{array}$ & 10 & $\begin{array}{l}\text { semi- } \\
\text { structured } \\
\text { interviews }\end{array}$ & BSc & empowered & yes & no & yes \\
\hline $\begin{array}{l}64 \\
\text { Drennan } \\
(2008)\end{array}$ & $\begin{array}{l}\text { survey; good } \\
\text { minor flaws }\end{array}$ & $\begin{array}{l}220 \text { from } \\
322 \text { target }\end{array}$ & $\begin{array}{l}\text { cross- } \\
\text { sectional } \\
\text { survey }\end{array}$ & MSc & promotional & yes & no & \\
\hline $\begin{array}{l}45 \\
\text { Ellis \& } \\
\text { Nolan } \\
(2005)\end{array}$ & $\begin{array}{l}\text { Qualitative } \\
\text { longitudinal; } \\
\text { minor flaws }\end{array}$ & $\begin{array}{l}15 \\
\text { students, } \\
21 \\
\text { managers } \\
1 \text { HEI }\end{array}$ & $\begin{array}{l}121 \text { semi- } \\
\text { structured } \\
\text { interviews }\end{array}$ & Diploma & positive changes & yes & no & yes \\
\hline $\begin{array}{l}56 \\
\text { Fraser \& } \\
\text { Titheringt } \\
\text { on (1991) }\end{array}$ & $\begin{array}{l}\text { survey; } \\
\text { fair/ poor }\end{array}$ & $\begin{array}{l}113 \\
\text { nurses } 3 \\
\text { HEIs }\end{array}$ & $\begin{array}{l}\text { postal } \\
\text { question- } \\
\text { naire }\end{array}$ & BSc & confidence & yes & yes & no \\
\hline $\begin{array}{l}57 \\
\text { Hardwick } \\
\text { \& Jordan } \\
\text { (2002) }\end{array}$ & $\begin{array}{l}\text { exploratory, } \\
\text { descriptive } \\
\text { survey; good } \\
\text { some minor } \\
\text { flaws }\end{array}$ & $\begin{array}{l}91 \\
\text { responses }\end{array}$ & $\begin{array}{l}\text { postal } \\
\text { question- } \\
\text { naire }\end{array}$ & BSc / MSc & $\begin{array}{l}\text { confidence in } \\
\text { practice }\end{array}$ & yes & no & yes \\
\hline $\begin{array}{l}44 \\
\text { Hughes } \\
(1990)\end{array}$ & $\begin{array}{l}\text { unstructured } \\
\text { interviews; } \\
\text { flawed }\end{array}$ & $\begin{array}{l}11 \text { nurses } \\
\& 6 \\
\text { managers }\end{array}$ & $\begin{array}{l}\text { evaluation } \\
\text { of module }\end{array}$ & Diploma & positive changes & yes & $\begin{array}{l}\text { yes } \\
\text { (noted by } \\
\text { manager) }\end{array}$ & \\
\hline $\begin{array}{l}67 \\
\text { Jordan et } \\
\text { al (1999) }\end{array}$ & $\begin{array}{l}\text { semi-structured } \\
\text { interviews } \\
\text { good }\end{array}$ & $\begin{array}{l}14 \text { in } 2 \\
\text { comparati } \\
\text { ve groups }\end{array}$ & $\begin{array}{l}\text { exploratory } \\
\text { cohort } \\
\text { study }\end{array}$ & Diploma & $\begin{array}{l}\text { improved skills \& } \\
\text { ability to educate }\end{array}$ & yes & yes & yes \\
\hline $\begin{array}{l}65 ; 66 \\
\text { Jordan/Jor } \\
\text { dan \& } \\
\text { Hughes } \\
(1998 \text { \& } \\
\text { 1998a) }\end{array}$ & $\begin{array}{l}\text { semi-structured } \\
\text { interviews; } \\
\text { fair minor flaws }\end{array}$ & $\begin{array}{l}29 \text { from } \\
44 \text { target }\end{array}$ & $\begin{array}{l}\text { action } \\
\text { research }\end{array}$ & Diploma & $\begin{array}{l}\text { see patients more } \\
\text { logically \& } \\
\text { holistically }\end{array}$ & yes & yes & yes \\
\hline $\begin{array}{l}68 \\
\text { Kenny } \\
(2001)\end{array}$ & $\begin{array}{l}\text { Pre \& post } \\
\text { course } \\
\text { questionnaire; } \\
\text { fair moderate } \\
\text { flaws }\end{array}$ & $\begin{array}{l}46 \text { nurses } \\
\& 20 \\
\text { managers }\end{array}$ & $\begin{array}{l}\text { Question- } \\
\text { naire }\end{array}$ & Diploma & $\begin{array}{l}\text { generally improved, } \\
\text { willingness to share } \\
\text { knowledge }\end{array}$ & yes & yes & $\begin{array}{l}\text { Implement- } \\
\text { tation } \\
\text { encouraged }\end{array}$ \\
\hline $\begin{array}{l}48 \\
\text { Lillibridge } \\
\text { \& Fox } \\
(2002)\end{array}$ & $\begin{array}{l}\text { interviews; } \\
\text { good minor } \\
\text { flaws }\end{array}$ & 12 & $\begin{array}{l}\text { qualitative } \\
\text { evaluation }\end{array}$ & BSc & $\begin{array}{l}\text { ritualistic behaviour } \\
\text { now recognised }\end{array}$ & yes & yes & yes \\
\hline
\end{tabular}

(Table 1 continued on page 202.) 
Table 1. (Continued.)

\begin{tabular}{|c|c|c|c|c|c|c|c|c|}
\hline Reference & $\begin{array}{l}\text { Quality of } \\
\text { methodology }\end{array}$ & $\begin{array}{l}\text { Sample } \\
\text { size }\end{array}$ & $\begin{array}{l}\text { Data } \\
\text { collection } \\
\text { method }\end{array}$ & $\begin{array}{l}\text { Education } \\
\text { level }\end{array}$ & $\begin{array}{l}\text { Attitudes \& } \\
\text { behaviours }\end{array}$ & $\begin{array}{l}\text { Personal } \\
\text { development }\end{array}$ & $\begin{array}{l}\text { Practice } \\
\text { affected }\end{array}$ & $\begin{array}{l}\text { Barriers to } \\
\text { practice } \\
\text { implementa- } \\
\text { tion noted }\end{array}$ \\
\hline $\begin{array}{l}53 \\
\text { Loftus \& } \\
\text { Thompson } \\
\text { (2002) }\end{array}$ & $\begin{array}{l}\text { Quiz } \\
\text { Fair/minor } \\
\text { flaws }\end{array}$ & 18 nurses & $\begin{array}{l}\text { evaluation } \\
\text { of module }\end{array}$ & Diploma & $\begin{array}{l}\text { decreased } \\
\text { knowledge } \\
\text { after course }\end{array}$ & in part & no & \\
\hline $\begin{array}{l}58 ; 59 ; 60 ; 61 ; \\
62 \\
\text { Pelletier et al } \\
(1994-2005)\end{array}$ & $\begin{array}{l}\text { exploratory } \\
\text { longitudinal } \\
\text { study } \\
\text { 1992-1996; } \\
\text { fair/poor major } \\
\text { flaws }\end{array}$ & $\begin{array}{l}403 \text { from } \\
827 \text { target } \\
\text { pop }\end{array}$ & $\begin{array}{l}\text { postal and } \\
\text { face-to-face } \\
\text { question- } \\
\text { naires }\end{array}$ & MSc & $\begin{array}{l}\text { Motivation, } \\
\text { Self- } \\
\text { confidence }\end{array}$ & yes & no & \\
\hline $\begin{array}{l}69 \\
\text { Rangeley \& } \\
\text { Arthurs (2004) }\end{array}$ & $\begin{array}{l}\text { taped } \\
\text { questionnaire; } \\
\text { good minor } \\
\text { flaws }\end{array}$ & $\begin{array}{l}145 \text { from } \\
\text { target of } \\
315\end{array}$ & $\begin{array}{l}\text { quantitative } \\
\text { and } \\
\text { qualitative } \\
\text { data }\end{array}$ & BSc & $\begin{array}{l}\text { self-esteem, } \\
\text { autonomy }\end{array}$ & yes & yes & yes \\
\hline $\begin{array}{l}52 \\
\text { Spencer (2006) }\end{array}$ & $\begin{array}{l}\text { semi-structured } \\
\text { interviews; } \\
\text { good minor } \\
\text { flaws }\end{array}$ & $\begin{array}{l}12 \text { nurses \& } \\
\text { midwives- } \\
\text { I HEI }\end{array}$ & $\begin{array}{l}\text { convenienc } \\
\text { e sample }\end{array}$ & MSc & $\begin{array}{l}\text { motivated, } \\
\text { able to } \\
\text { challenge }\end{array}$ & yes & no & yes \\
\hline $\begin{array}{l}47 \\
\text { Stanley (2003) }\end{array}$ & $\begin{array}{l}\text { unstructured } \\
\text { interviews; } \\
\text { good }\end{array}$ & $\begin{array}{l}\text { purposive } \\
9 \text { staff } \\
1 \text { HEI }\end{array}$ & $\begin{array}{l}\text { qualitative } \\
\text { phenomen- } \\
\text { ology }\end{array}$ & BSc & $\begin{array}{l}\text { motivation } \\
\text { not sustained }\end{array}$ & yes & no & \\
\hline $\begin{array}{l}51 \\
\text { Stavropoulou } \\
\text { \& Biley (1997) }\end{array}$ & $\begin{array}{l}\text { open ended } \\
\text { interviews; } \\
\text { poor, flawed }\end{array}$ & $\begin{array}{l}9 \text { nurses } \\
1 \text { HEI }\end{array}$ & $\begin{array}{l}\text { inductive, } \\
\text { grounded } \\
\text { theory }\end{array}$ & MSc & $\begin{array}{l}\text { intellectually } \\
\text { challenging }\end{array}$ & yes & no & \\
\hline $\begin{array}{l}63 \\
\text { Whyte et al } \\
(2000)\end{array}$ & $\begin{array}{l}\text { survey } 10 \text { year } \\
\text { follow up; } \\
\text { fair minor flaws }\end{array}$ & $\begin{array}{l}109 \text { from } \\
190\end{array}$ & $\begin{array}{l}\text { postal } \\
\text { questionnai } \\
\text { re }\end{array}$ & MSc & $\begin{array}{l}\text { self-esteem, } \\
\text { analytical } \\
\text { skills }\end{array}$ & yes & no & \\
\hline $\begin{array}{l}55 \\
\text { Wildman et al } \\
(1990)\end{array}$ & $\begin{array}{l}\text { exploratory } \\
\text { descriptive: } \\
\text { fair/poor }\end{array}$ & 113 nurses & $\begin{array}{l}45 \text { item } \\
\text { postal } \\
\text { questionnai } \\
\text { re }\end{array}$ & Diploma & $\begin{array}{l}\text { assertiveness } \\
\text { confidence }\end{array}$ & yes & yes & yes \\
\hline $\begin{array}{l}54 \\
\text { Wyatt (2007) }\end{array}$ & $\begin{array}{l}\text { postal survey; } \\
\text { good /fair minor } \\
\text { flaws }\end{array}$ & 171 nurses & $\begin{array}{l}\text { descriptive } \\
\text { survey }\end{array}$ & Diploma & $\begin{array}{l}\text { improved } \\
\text { persona } \\
\text { practice }\end{array}$ & yes & yes & \\
\hline
\end{tabular}

Objective 2 - To identify the knowledge, skills, behaviours, and/or attitudes that registered nurses acquire following post-registration higher education.

The findings show that nurses do demonstrate some changes in knowledge, skills, behaviours, and /or attitudes following $\mathrm{CPE}$, in the following ways:

1) Subject specific knowledge may increase ${ }^{[44]}$ or existing knowledge may be reinforced ${ }^{[54]}$.

2) Knowledge of research develops, particularly during the diploma pathways ${ }^{[55]}$, where participants learn about study designs, searching and appraising. There is evidence that knowledge of research develops incrementally through the higher levels of education.

3) All studies report the acquisition of skills, although Hughes ${ }^{[44]}$, Pelletier ${ }^{[58-62]}$, Whyte et al. ${ }^{[63]}$, and Birks et al. ${ }^{[50]}$ found a greater range.

4) Nurses who studied at diploma level reported a greater range of skills that directly relate to patient care. Such skills included assessment, planning, and evaluation of patients' care needs ${ }^{[46]}$. 
5) Most studies report the development of academic and professional skills, particularly communication. However, the study participants of six studies did not report changes in communication skills ${ }^{[47,52,53,56,64,67]}$.

6) The skills of critical analysis and thinking, leadership, and research were evident across all levels of education. However, these skills were predominantly seen in education above diploma level ${ }^{[48-51,57-63]}$.

7) All studies reflect a change in attitudes and behaviour, particular related to sharing knowledge and identifying learning needs. The diploma participants of Hughes ${ }^{[44]}$ and Wildman et al. ${ }^{[55]}$ demonstrated behavioural changes in relation to research skills, by sharing evidence-based practice through the of implementing journal clubs. Five studies report participants pursued education to improve their chances in teaching careers ${ }^{[47,56,57,63,64]}$.

8) All studies report personal development. Self-confidence was seen to increase and this was particularly noted by managers, in relation to communication and challenging practice ${ }^{[44,45]}$.

\section{Objective 3 - To establish how registered nurses apply knowledge, skills, behaviours, and/or attitudes to practice, following post-registration higher education.}

The findings for the application of change to practice are less clear.

1) Only those participants who had undertaken diploma level education, or isolated modules, demonstrated changes in practice specifically through increased knowledge ${ }^{[44-46,53,54,65-69]}$. Such skills included assessment, planning, and evaluation of patients' care needs.

2) Newfound knowledge and skills could not be applied or sustained in practice and thus the participants in the original research reported losing interest when trying to make practice changes ${ }^{[45,56,65-67]}$.

3) Some participants completing degree level modules recognised ritualised practice and implemented evidence-based care. The practitioners of degree level modules ${ }^{[46,69]}$ and some degree programmes ${ }^{[49,50]}$, provided examples of how they had used research skills in practice.

4) There is strong evidence that participants are unable to demonstrate changes in practice because of work-related barriers $[45,48,49,52,55-57,65-67,69]$.

5) Several studies indicate that higher education qualifications secure promotion ${ }^{[49,54,56,58-64]}$ and two studies report the motivation for education as simply personal benefit ${ }^{[44,54]}$.

\section{Discussion}

\section{Objective 1 - the validity and reliability of the primary evidence.}

The validity and reliability of the primary data was very varied. There were noticeable inconsistencies in reporting the methodologies, and this may be reflected in the quality of the review. Each piece of original research appeared to address the stated aims. Three studies included the nurse manager's view ${ }^{[44,45,68]}$. Managers' perspectives were relevant to confirm the registered nurses' perceptions of their care performance following education. All 21 studies involved self-reporting from the study participants as data collection was reliant on recall, which limits the validity of the findings ${ }^{[85]}$. This suggests that observational methods may be the way forward in future research.

Funding issues, ethical approval, sampling methods, participant characteristics, data analysis methods, and limitations in the primary research were all found to be very variably reported. Despite these concerns about heterogeneity, the approaches used within the studies were similar. Therefore, the studies were classed as homogenous, where the methodological ingredients are consistent ${ }^{[34]}$. The design of all the mixed methods studies reviewed had a dominant qualitative focus and the descriptive nature of the non-experimental designs also closely aligned them to the qualitative studies. The lack of information regarding participant characteristics did not enable full examination of similarities. 
However those characteristics reported were comparable, suggesting that the studies were also consistent in setting and participant type.

The criteria for robustness by Hawker et al ${ }^{[37]}$ were applied to each primary study, which allowed each study to be scored in trustworthiness, appropriateness, and relevance. Despite some methodological flaws, the majority of studies were rated fair or good for trustworthiness. Two studies were rated as poor ${ }^{[53,56]}$. All other studies were rated fair or good. The appropriateness of most primary designs was good, however, Hughes ${ }^{[44]}$, Pelletier et al ${ }^{[58-62]}$, and Loftus and Thompson ${ }^{[53]}$ were only rated fair. Overall the relevance of the studies was consistent, and even those studies deemed methodologically weak, contributed towards answering the research question ${ }^{[76]}$.

Seventeen studies provided "good" overall quality, but Hughes ${ }^{[44]}$, Loftus and Thompson ${ }^{[53]}$, Fraser and Titherington ${ }^{[56]}$ and Pelletier et al ${ }^{[58-62]}$ were only rated "fair". The isolated assessment of some studies found both methods and findings weak. However, when the findings of all studies were combined, they appeared strong, which provided a robust review overall. This reiterates the value and purpose of a systematic review (Zimmer, 2006).

\section{Objective 2 - What Knowledge, Skills, Attitudes \& Behaviours do Practitioners Obtain?}

\section{Knowledge}

Knowledge was an area in which the participants reported the least development. The participants of studies involving isolated modules reported the most increase in knowledge. Such knowledge was subject-specific, as would be expected following intense programmes of education. However, Wyatt ${ }^{[54]}$ report that education only reinforced existing knowledge, although this was seen positively and not as negative reflections of course delivery. These participants worked in specialised areas of practice, which suggests a sound knowledge base already existed.

There is evidence of new knowledge associated with research theory across all levels of education [44, 48-50, 55, 57-63, 69]. Knowledge of research develops during diploma pathways ${ }^{[55]}$, and appears to develop incrementally through the higher levels of education.

Those researchers investigating complete Bachelors and Masters Programmes report a general understanding of the wider healthcare issues. Birks et al. ${ }^{[50]}$ were the only researchers to report specific knowledge development from a degree programme. This may be due to participants finding difficulty pinpointing knowledge development as they follow complete pathways, which they can do with isolated modules. However, an existing knowledge base may also be the cause, where previous and new knowledge are merging.

Skills

Skills were themed as academic skills, professional skills, and those that directly affect patients. All studies report the development of a wide range of skills following education. This is most likely due to the primary designs, multiple data collection, and the perspectives used by primary researchers. However, Hughes ${ }^{[4]}$ and Birks et al ${ }^{[50]}$ knew their participants, which introduced the potential for bias by possible over-enthusiastic reporting ${ }^{[86]}$.

Registered nurses who studied above diploma level predominantly reported the development of academic and professional skills, but it is not clear when they noticed this; unless the recognised development of skills relates to some "aha" moments. The participants of Stavropoulou and Biley ${ }^{[51]}$ report gradual effects of education because they did not immediately recognise their skill acquirement. This highlights the way nurses need time to reflect and implement practice changes, and perhaps accounts for why research findings differ on whether education has an effect on practice.

The dominance of academic skills acquisition in this post-qualifying research, reiterates, to some extent, the concerns expressed at the inception of Project 2000, that moving pre-registration education into HEIs would create "thinkers" not 
“doers". So the development of these skills through HE studies appears to provide the "building blocks" that registered (non- diplomat or graduate) practitioners draw upon for the benefit of patient care. In this way, the academic skills obtained following post-registration education are the "tools of the trade" and nurses become more thinking 'doers'. However, it is possible that the development of academic and professional skills are the result of all previous education and clinical experience. It is difficult to isolate the effects of academic skills when subsequent education may have been undertaken since the primary research was conducted. Therefore, due to the nature of some primary designs, and the data reported, it was impossible to judge how far the variables of experience and other education influenced the results of this review.

\section{Attitudes \& Behaviours}

Sharing of knowledge and recognition of learning needs were most prominent in those participants who had studied at diploma level. This links to the level of knowledge gained by these participants, and indicates they were motivated to share what they had learned. It also shows that diploma level education is the beginning of lifelong learning, where nurses can identify gaps in their existing knowledge. However, those who completed Bachelors and Masters Programmes did not report recognition of their educational needs. Whilst these nurses appear to have developed into lifelong learners they view their programme of study as complete and so have met their present learning needs.

\section{Personal Development}

Personal development was reported in all studies, where the concept of self-confidence dominated, being strongly linked to the professional skills of communication and challenging practice. Managers in some studies commented on the perceptions of personal change and development ${ }^{[44,45,68]}$. The impact of education on personal development was more apparent in those nurses who studied beyond diploma level at Degree or Masters Level. Personal development also related to feelings of self-esteem, where participants felt valued and respected and hence consequently affects job satisfaction. This provides nurses with a solid ability to influence changes that benefit patients ${ }^{[47-52,57,65,66]}$. This reinforces the evidence, from the review studies that whilst some participants demonstrated or cited links between their education and practice, it was not apparent across all studies of the review.

\section{Objective 3 - How do Practitioners Apply Knowledge, Skills, Attitudes \& Behaviours to Practice?}

The evidence from the review studies indicates that post-registration higher education does enable registered nurses to develop knowledge, skills, and positive attitudes. Whilst some participants demonstrated or cited links between their education and practice, it was only apparent in some studies ${ }^{[44-46,49,50,54,55,65-69]}$.

\section{Knowledge in Practice}

Only those participants who had undertaken studies at diploma level, or undertaken isolated modules demonstrated changes in practice, through knowledge. Drennan and Jordan identified where changes in practice stemmed from knowledge of medication and side effects; participants had implemented robust patient monitoring; preventing serious health implications ${ }^{[65,66]}$. The participants of Kenny ${ }^{[68]}$ and Wyatt ${ }^{[54]}$ implemented prescribing protocols to reflect the knowledge gained of symptom control in palliative care.

This shows how education can develop clinical awareness, from which patients can only benefit. The practice links made by the participants reflect their reported changes in knowledge.

The participants of the complete diploma programme in Wildman et al ${ }^{[55]}$ also demonstrated their knowledge clinically. However, Wildman et al ${ }^{[55]}$ report that an increase in knowledge also had a negative effect on practice. This was noted in relation to legal and ethical issues, where nurses were cautious in dealing with some aspects of patient care and avoided difficult situations by "letting Sister deal with it". 


\section{Skills, Attitudes \& Behaviours in Practice}

The knowledge gained at diploma level transposed into practical skills ${ }^{[65-67]}$. A few diploma level participants demonstrated academic and professional skills in practice ${ }^{[44-65,66,68,69]}$ and these skills link directly to the knowledge obtained. These skills were communication, challenging practice and change management ${ }^{[54,65,66,68]}$. The diploma participants of Hughes ${ }^{[44]}$ and Wildman et al. ${ }^{[55]}$ demonstrated behavioural changes in relation to research skills.

The nurses on degree level modules Arthurs \& Rangeley ${ }^{[69]}$, Atkinson \& Tawse ${ }^{[46]}$ and some degree programmes ${ }^{[49,50]}$, provided examples of how they had used research skills in practice. Without these skills, these participants would have not recognised ritualised practice and been unable to implemented evidenced-based practice as a result. The participants of Atkinson and Tawse ${ }^{[46]}$ also used communication skills to form better relationships with patients; this and the other practice changes demonstrated a direct impact on patient care.

Whilst the participants of Bachelors and Masters Programmes reported a wide range of skills, they were unable to cite examples of how their practice had changed ${ }^{[47,48,51,52,56,57,63]}$. Whilst this reinforces the concerns, within the background literature, it is possible that the retrospective nature of these studies confirmed establishment of educational effect. These nurses could already be performing at advanced levels, where the additional educational effects and experience cannot be isolated. This appears to contradict with the advantages of retrospective studies, where researchers may not have considered experience as a confounding variable ${ }^{[87]}$.

Participants who demonstrated their newfound knowledge and skills in practice, did not sustain these and lost interest $^{[44,45,65-67]}$. All these participants were on isolated diploma modules and therefore the failed sustainability could be associated with the short duration of the educational experience. Failed sustainability could explain why nurses ride the academic "merry-go-round" [19], where nurses demand further education because they are continually recognising deficits in their knowledge and skills. However, whilst not entirely determined from the review evidence, this does support that view that the effects of education, (above diploma level) develop more gradually and are long-term.

\section{Barriers to Implementing Educational Effects}

There is strong evidence that participants are unable to demonstrate changes because of work-related barriers. Eleven

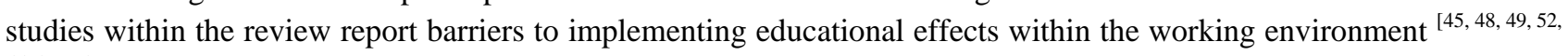
55-57, 65-67, 69]. Four of these studies report unsustainable effects, which suggest there is a link between barriers and sustainable educational effects. The barriers most noteworthy from the evidence are those of managers $[43,48,56,57,65-67,69]$ and peers ${ }^{[48,49,52,57,65,66,69]}$, where conflict arises amongst colleagues. Participants within the reviewed studies suggest this is because managers and colleagues feel inferior, and this is supported from within existing literature ${ }^{[19,25,43]}$.

Hardwick and Jordan ${ }^{[57]}$ claim nurses "choose" not to implement new practices after education because it is easier than "battling" against managers. Three studies report nurses believe their managers do not value or recognize their skills ${ }^{[52,56,57]}$. Lack of managerial support may explain why some of those nurse cannot identify how CPE has affected their practice. Ironically, managers claim they see no return on their educational investments, but it appears they may be contributing to the cause ${ }^{[22]}$.

\section{Motivation for Education}

Motivation to undertake education could be seen as personal benefit, with little regard for the benefits of patient care ${ }^{[44,54]}$. However other studies ${ }^{[45,47,50-52,56,57,65,66,68]}$ reported that nurses were motivated to pursue higher education to update their professional knowledge in order to be on a par with those undertaking pre-registration diploma or graduate studies. Such motivation is supported within the existing literature ${ }^{[5,8,13]}$.

Other studies cited promotional opportunity as a reason for pursuing education ${ }^{[44,47-49,50,51,54,57,64-66]}$. Spencer ${ }^{[52]}$ found that whilst nurses were willing to undertake studies and then leave a hands-on care post, to secure senior positions, this was 
because seniority enabled them to readily influence and empower evidence-based practice. However Pelletier et al. ${ }^{[58-62]}$ and Spencer ${ }^{[52]}$ also found that some participants believe the possession of higher education qualifications had no relevance on practice, unless it was to secure a position of seniority. Therefore, the motivation for education may be to improve patient care indirectly, through promotion to a senior position. Finally if staff do not hold positions of seniority, they have to strive to overcome managerial constraints to implementing practice changes ${ }^{[48,49,52,57,65,66]}$.

\section{Limitations of the review}

Reviews are usually undertaken by a team of researchers to eliminate subjectivity through joint decisions of the process. As a lone researcher with supervisory support has undertaken this review, it is possible that subjectivity and bias has not been eliminated during all methodological stages ${ }^{[88]}$. However, every attempt to minimise subjectivity, and maximise rigour, was made by following reliable guidance and frameworks ${ }^{[34,35,40,71,80]}$, and reflexivity has been an important part of the process.

It is possible that the search process, despite retrieving large numbers of citations, did not capture all relevant evidence. Whilst, some researchers claim it is acceptable not to aim to include all available evidence ${ }^{[42]}$, more time may have also facilitated the pursuit of unpublished works, dissertations and thesis, which are conspicuous by their absence.

Although interpretation was confirmed by comparison with the preliminary extraction ${ }^{[88]}$, there is the possibility that the researcher may have introduced bias during data extraction. During data extraction, every effort was made to preserve the integrity and original context of the primary data. Whilst, interpretation of findings could have been confirmed with the primary researchers, any misinterpretation of the findings was unintentional, and not for "fitting" the findings with the review aim ${ }^{[89]}$. Consequently, the researcher might have made erroneous decisions about the trustworthiness and methodological soundness. These decisions might have exaggerated or under-exaggerated the quality of the evidence, which may have skewed the review outcome ${ }^{[74]}$.

Whilst narrative synthesis is the simplest method of synthesis ${ }^{[80]}$, attempts were made to explore relationships through juxtaposition and tabulation of findings. Whilst common themes and patterns were determined, this level of understanding may have been deepened by an alternative synthesis method such as meta-synthesis or meta-summary. Consequently, alternative synthesis methods may have been more convincing to those who are sceptical about the impact of CPE on practice.

\section{Conclusion}

In conclusion, this systematic review has appraised the evidence relating to the impact and effects of formal continuing professional education on professional practice. The study approach has been justified by an abundant, but inconclusive, available evidence relating to post-registration education. Twenty-one studies have been scrutinised, appraised, and synthesised. The synthesised findings found a wealth of positive effect both personally and in practice.

Registered nurses undertaking diploma level education develop a greater sphere of subject-specific knowledge, and demonstrate application of this knowledge to clinical practice. This supports the existing evidence that diploma education develops "doers". Whilst post-registration education develops skilled nurses, there is a distinct practice gap where the effects of diploma level education are not sustainable. This could explain the "merry-go-round" analogy, where nurses are constantly identifying knowledge gaps.

The knowledge obtained by degree level education is less visible, and these nurses generally appear to build on existing knowledge to develop a broader understanding of practice issues. As these registered nurses continue their studies to 
degree level they acquire further professional and academic skills and this supports the existing evidence, that degree education develops "thinkers".

Key skills such as research, communication, leadership, and critical analysis are evident in all registered nurses, and these develop incrementally as each level of education is undertaken. The skills acquired during degree programmes do not appear to impact directly on patient care, yet they enable creative, adaptable, and confident nurses. They develop into lifelong learners who recognise the need to update ritualistic practice, from which patients do directly benefit. The effects of degree level education develop gradually, accumulating over time, and therefore are long-term. This explains why degree nurses cannot immediately recognise the benefits, and contributes to the claim that higher education has no demonstrable effects in practice.

The review evidence also indicates barriers to educational effects within the workplace, which mostly appear to emanate from managerial constraints. The results suggest that managers may be hindering nurses' practical ability to implement new practice, and reinforces the concerns that education has limited benefit to patient care. The evidence suggests managers' insecurity may be an influencing factor; which highlights the need for additional research to explore the reasons why managers appear unsupportive of the implementation of new practices following education. Awareness of these reasons could help gain understanding and overcome the root cause of why educational effects are not always evident in practice.

The background literature claims some stakeholders believe registered nurses pursue education for personal reward. However, the evidence within this review provides little support to this claim. Instead, the evidence confirms nurses seek post-registration education to maintain professional credence with pre-registrants and to increase the chances of promotion, where they can be in positions of influence.

The researcher has been unable to establish if the nurses' developmental effects are truly attributed to post-registration education. This is due to the gaps within reporting of the primary studies, and whilst the synthesis has strengthened the credibility of the findings, this review highlights the gaps within the existing evidence. The majority of studies were retrospective, where the possibility of recall bias cannot be eliminated. This reiterates that the overall weight scores have been overemphasised. Further research needs to be undertaken, which incorporates other perspectives to corroborate nurses' reports. Whilst, no one design is better and all greatly contribute to answering research questions, longitudinal methodologies appear best suited to reduce the risk of recall bias. Such methods would facilitate the exploration of behavioural patterns overtime, which would benefit from the incorporation of observation and multiple perspectives.

The researcher excluded studies involving new graduates since these would examine the effects of pre-registration education. Comparison of the educational effects between new graduates and established practitioners might confirm and strengthen the synthesis findings. Such comparison would make an interesting future study, where exploration could determine if these practitioners obtain the same level of knowledge and skills, and follow the same patterns of development.

In conclusion, whilst the researcher has interpreted the synthesised data in favour of post-registration education, the methodological gaps still renders the evidence inconclusive. This highlights the value of systematic reviews. Ultimately, identification of the research gaps has satisfied one purpose of the review. However, whilst the research objectives have been met, until further research is available, the research question remains unanswered.

\section{References}

[1] Gallagher, L. Continuing Education in Nursing: A Concept Analysis. Nurse Education Today. 2006; 27(5): $466-473$.

PMid:17109998 http://dx.doi.org/10.1016/j.nedt.2006.08.007

[2] Gopee, N. Facilitating the Implementation of Lifelong Learning in Nursing. British Journal of Nursing. 2005; $14(14)$ : 761-767. PMid:16116381 
[3] Magill-Cuerden, J. Leading and Managing Professional Development - Improving Patient Care. Journal of Nursing Management. 2007; 15(6): 563-566. PMid:17688560 http://dx.doi.org/10.1111/j.1365-2834.2007.00805.x

[4] Royal College of Nursing. A Joint Statement on Continuing Professional Development for Health and Social Care Practitioners. London, RCN. 2007.

[5] Health Professions Council. Standards for Continuing Professional Development. London, HPC. 2005.

[6] Roberts, P. \& Priest, H. Education: Improving Quality through Service Enhancement. Nursing Standard. 2007; 21(18): 42-46.

[7] Ring, N. A Personal and Historical Investigation of the Career Trends of UK Graduate Nurses Qualifying between 1970 and 1989. Journal of Advanced Nursing. 2002; 40(2): 199-209. PMid:12366650 http://dx.doi.org/10.1046/j.1365-2648.2002.02362.x

[8] Linsley, P; Kane, R; McKinnon, J; Spencer, R. \& Simpson, T. Preparing for the Future: Nurse Education and Workforce Development. Quality in Primary Care. 2008; 16(3): 171-176. PMid:18700098

[9] Greenwood, J. Critique of the Graduate Nurse: An International Perspective. Nurse Education Today. 2009; 20(1): 17-23. PMid:11138212 http://dx.doi.org/10.1054/nedt.2000.0424

[10] Owen, G.M. For Better, For Worse: Nursing in Higher Education. Journal of Advanced Nursing. 1988; 13(1): 3-13. PMid:3372883 http://dx.doi.org/10.1111/j.1365-2648.1988.tb01386.x

[11] Illingworth, P. \& Chelvanayagam, S. Benefits of Interprofessional Education in Health Care. British Journal of Nursing. 2007; 16(2): 121-124. PMid:17353824

[12] Carlisle, C. Post-registration Degrees in Nursing: A Time for Evaluation. Nurse Education Today. 1991; 11(4): $295-302$. http://dx.doi.org/10.1016/0260-6917(91)90093-P

[13] Beach, D.J. Professional Knowledge and its Impact on Nursing Practice. Nurse Education in Practice. 2002; 2(2): 80-86. http://dx.doi.org/10.1054/nepr.2002.0064

[14] Jasper, M. The First Year as a Staff Nurse: The Experiences of a First Cohort of Project 2000 Nurses in a Demonstration Pilot. Journal of Advanced Nursing. 1996; 24(4): 779-790. PMid:8894896 http://dx.doi.org/10.1046/j.1365-2648.1996.25517.x

[15] Hickey, G. The Challenge of Change in Nurse Education: Traditionally Trained Nurses’ Perceptions of Project 2000. Nurse Education Today. 1996; 16(6): 389-396. http://dx.doi.org/10.1016/S0260-6917(96)80043-8

[16] Royal College of Nursing. RCN Hails Degree-entry Plans. RCN Bulletin 2009; 240: 1.

[17] Nursing and Midwifery Council. The PREP Handbook. London, NMC. 2008.

[18] Bahn, D. Reasons for Post-registration Learning: Impact of the Learning Experience. Nurse Education Today. 2007; 27(7): 715-722. PMid:17126455 http://dx.doi.org/10.1016/j.nedt.2006.10.005

[19] Powell, G. Do Nurses go on Courses just to Collect Tickets? British Journal of Nursing. 2001; 10(3): 138. PMid:12170655

[20] Munro, K.M. Continuing Professional Development and the Charity Paradigm: Interrelated Individual, Collective and Organisational Issues about Continuing Professional Development. Nurse Education Today. 2008; 28(8): 953-961. PMid:18599163 http://dx.doi.org/10.1016/j.nedt.2008.05.015

[21] O’Sullivan, J. Continuing Professional Development - Is it Beneficial? Physiotherapy. 2004; 90(4): 174-175.

[22] Joyce, P. \& Cowman, S. Continuing Professional Development: Investment or Expectation? Journal of Nursing Management. 2007; 15(6): 626-633. PMid:17688568 http://dx.doi.org/10.1111/j.1365-2834.2007.00683.x

[23] Lawton, S. \& Wimpenny, P. Continuing Professional Development: A Review. Nursing Standard. 2003; 17(24): 41-44.

[24] Draper, J. \& Clark, L. Impact of Continuing Professional Development on Practice: The Rhetoric and the Reality. Nurse Education Today. 2007; 27(6): 515-517. PMid:17650437 http://dx.doi.org/10.1016/j.nedt.2007.07.001

[25] Hughes, E. Nurses’ Perceptions of Continuing Professional Development. Nursing Standard. 2005; 19(43): 41-49.

[26] Thompson, D. Beyond Motivation: A model of Registered Nurses’ Participation and Persistence in Baccalaureate Nursing Programs. Adult Education Quarterly. 1992; 42(2): 94-105. http://dx.doi.org/10.1177/0001848192042002003

[27] Dowswell, T; Hewison, J. \& Hinds, M. Motivational Forces Affecting Participation in Post-registration Degree Course and Effects on Home and Work Life: A Qualitative Study. Journal of Advanced Nursing. 1998; 28(6): 1326-1333. PMid:9888379 http://dx.doi.org/10.1046/j.1365-2648.1998.00841.x

[28] Chiu, L.H. Motivation for Nurses Undertaking a Post-registration Qualification in Malaysia. International Nursing Review. 2005; 52(1): 46-51. PMid:15725276 http://dx.doi.org/10.1111/j.1466-7657.2004.00415.x

[29] Cooley, M. Nurses' Motivations for Studying Third Level Post-registration Nursing Programmes and the Effects of Studying on their Personal and Work Lives. Nurse Education Today. 2007; 28(5): 588-594. PMid:18313177 http://dx.doi.org/10.1016/j.nedt.2007.11.002

[30] Griscti, O. \& Jacono, J. Effectiveness of Continuing Education Programmes in Nursing: Literature Review. Journal of Advanced Nursing. 2006; 55(4): 449-456. PMid:16866840 http://dx.doi.org/10.1111/j.1365-2648.2006.03940.x

[31] Gould, D; Drey, N. \& Berridge, E. Nurses’ Experiences of Continuing Professional Development. Nurse Education Today. 2007; 27(6): 602-609. PMid:17109999 http://dx.doi.org/10.1016/j.nedt.2006.08.021 
[32] Sandelowski, M. Reading, Writing and Systematic Review. Journal of Advanced Nursing. 2008; 64(1): 104-110. PMid:18721156 http://dx.doi.org/10.1111/j.1365-2648.2008.04813.x

[33] Centre for Reviews and Dissemination. Systematic Reviews: Guidance for Undertaking Reviews in Health Care. University of York, York, CRD. 2009.

[34] Greenhalgh, T. How to Read a Paper: The Basics of Evidence-based Medicine 3rd Ed. Oxford, Blackwell Publishing. 2006.

[35] Magarey, J. Elements of a Systematic Review. International Journal of Nursing Practice. 2001; 7(6): 376-382. PMid:11785440 http://dx.doi.org/10.1046/j.1440-172X.2001.00295.x

[36] Needleman, I. A Guide to Systematic Reviews. Journal of Clinical Periodontology. 2002; 29 (supplement 3): 6-9. PMid:12787202 http://dx.doi.org/10.1034/j.1600-051X.29.s3.15.X

[37] Hawker, S, Payne, S, Kerr, C, Hardey, M. \& Powell, J. Appraising the Evidence: Reviewing Disparate Data Systematically [Internet]. Qualitative Health Research. 2002; 12(9): 1284-1299. http://dx.doi.org/10.1177/1049732302238251. Available from: https://qhr.sagepub.com/cgi/content/abstract/12/9/1284 [date accessed: March 2nd 2010] PMid:12448672 http://dx.doi.org/10.1177/1049732302238251

[38] Fink, A. Conducting Research Literature Reviews: From the Internet to Paper, 2nd Ed. London, Sage Publications. 2005.

[39] Lloyd-Jones. M. Application of Systematic review Methods to Qualitative Research: Practical Issues. Journal of Advanced Nursing. 2004; 48(3): 271-278. PMid:15488041 http://dx.doi.org/10.1111/j.1365-2648.2004.03196.x

[40] Greenhalgh, T, Robert, G, Macfarlane, F, Bate, P, Kyriakidou, O. \& Peacock, R. Storylines of Research in Diffusion of Innovation: A Meta-narrative Approach to Systematic review. Social Science and Medicine. 2005; 61(2): 417-430. http://dx.doi.org/10.1016/j.socscimed.2004.12.001

[41] Higgins, J.P.T. \& Green, S (eds). Cochrane Handbook for Systematic Reviews of Interventions 4.2.6 [Internet] [updated September 2006]. The Cochrane Collaboration. Available from: https://www.cochrane.org/resources/handbook/hbook.htm [date accessed: September 2nd 2009]

[42] Dixon-Woods, M, Cavers, D, Agarwal, S, Annandale, A, Harvey, J, Hsu, R, Katbamna, S, et al. Conducting a Critical Interpretative Synthesis of the Literature on Access to Healthcare by Vulnerable Patients (2006) [Interent]. BMC Medical Research Methodology. 2006; 6(35). PMid:16872487 http://dx.doi.org/10.1186/1471-2288-6-35. Available from: https://www.biomedcentral.com [date accessed February 5th 2010]

[43] Gijbels, H; O’Connell, R; Dalton-O’Connor, C. \& O’Donovan, M. A Systematic Review Evaluating the Impact of Post-registration Nursing and Midwifery Education on Practice [Interent]. Nurse Education in Practice. http://dx.doi.org/ 10.1016/j.nepr.2009.03.011. Available from: https://www.elsevier.com/nepr [date accessed May 6th 2009]

[44] Hughes, P. Evaluating the Impact of Continual Professional Education (ENB 941). Nurse Education Today. 1990; 10(6): $428-436$. http://dx.doi.org/10.1016/0260-6917(90)90105-Y

[45] Ellis, L. \& Nolan, M. Illuminating Continuing Professional Education: Unpacking the Black Box. International Journal of Nursing Studies. 2005; 42(1): 97-106. PMid:15582643 http://dx.doi.org/10.1016/j.ijnurstu.2004.05.006

[46] Atkinson, J. \& Tawse, S. Exploring Haematology Nurses’ Perceptions of Specialist Education’s Contribution to Care Delivery and the Development of Expertise. Nurse Education Today. 2007; 27(6): 627-634. PMid:17126955 http://dx.doi.org/10.1016/j.nedt.2006.09.011

[47] Stanley, H. The Journey to becoming a Graduate Nurse: A Study of the Lived Experiences of Part-time Post-registration Students. Nurse Education in Practice. 2003; 3(2): 62-71. http://dx.doi.org/10.1016/S1471-5953(02)00055-0

[48] Lillibridge, J. \& Fox, S.D. RN to BSN Education: What do RNs Think? Nurse Educator. 2005; 30(1): 12-16. PMid:15685019 http://dx.doi.org/10.1097/00006223-200501000-00005

[49] Chiu, L.H. Malaysian Registered Nurses’ Professional Learning. International Journal of Nursing Education Scholarship. 2006; 3(1): 1-12.

[50] Birks, M; Francis, K. \& Chapman, Y. Seeking Knowledge, Discovering Learning: Uncovering the Impetus for Baccalaureate Nursing Studies in Malaysian Borneo. International Journal of Nursing Practice. 2009; 15(3): 164-171. PMid:19531074 http://dx.doi.org/10.1111/j.1440-172X.2009.01741.x

[51] Stavropoulou, A. \& Biley, F.C. The Influence of Postgraduate Studies on Nurses' Professional and Personal Development. European Nurse. 1997; 2(1): 7-15.

[52] Spencer, R. Nurses', Midwives', and Health Visitors Perceptions of the Impact of Higher Education on Professional Practice. Nurse Education Today. 2006; 26(1): 45-53. PMid:16122844 http://dx.doi.org/10.1016/j.nedt.2005.06.006

[53] Loftus, L.A. \& Thompson, E. An Evaluation of a Palliative Care Course for Generic Nurses. International Journal of Palliative Care. 2002; 8(7): 354-460.

[54] Wyatt, D. How do Participants of a Post Registration Oncology Nursing Course Perceive that the Course Influences their Practice? European Journal of Oncology Nursing. 2007(a); 11(2): 168-178. 
[55] Wildman, S; Weale, A; Rodney, C. \& Pritchard, J. The Impact of higher Education for Post-registration Nurses on their Subsequent Clinical Practice: An Exploration of Students’ Views. Journal of Advanced Nursing. 1999; 29(1): 246-253. PMid:10064305 http://dx.doi.org/10.1046/j.1365-2648.1999.00832.x

[56] Fraser, M. \& Titherington, R. Where are they now? The Career Paths of Graduates from Post-registration Degrees in Nursing in England. International Journal of Nursing Studies. 1991; 28(3): 257-265. http://dx.doi.org/10.1016/0020-7489(91)90019-Y

[57] Hardwick, S. \& Jordan, S. The Impact of Part-time Post-registration Degrees on Practice. Journal of Advanced Nursing. 2002; 38(5): p524-535. PMid:12028286 http://dx.doi.org/10.1046/j.1365-2648.2002.02214.x

[58] Pelletier, D; Duffield, C; Gallagher, R; Soars, L; Donoghue, J. \& Adams, A. The Effects of Graduate Nurse Education on Clinical Practice and Career Paths: A Pilot Study. Nurse Education Today. 1994; 14(4): 314-321. http://dx.doi.org/10.1016/0260-6917(94)90143-0

[59] Pelletier, D, Donoghue, J, Duffield, C. \& Adams, A. The Impact of Graduate Education on the Career Paths of Nurses. Australian Journal of Advanced Nursing. 1998; 15(3): 23-30. PMid:9807273

[60] Pelletier, D; Donoghue, J; Duffield, C. \& Adams, A. Nurses’ Perceptions of their Professional Growth on Completion of Two Years of Postgraduate Education. Australian Journal of Advanced Nursing. 1998a; 16(2): 26-35. PMid:10196874

[61] Pelletier, D; Donoghue, J. \& Duffield, C. Australian Nurses' Perceptions of the Impact of their Postgraduate Studies on their Patient Care Activities. Nurse Education Today. 2003; 23(6) p434-442. http://dx.doi.org/10.1016/S0260-6917(03)00069-8

[62] Pelletier, D; Donoghue, J. \& Duffield, C. Understanding the Nursing Workforce: A Longitudinal Study of Australian Nurses Six Years after Graduate Study. Australian Journal of Advanced Nursing. 2005; 23(1): 37-43. PMid:16496816

[63] Whyte, D; Lugton, J. \& Fawcett, T. Fit for Purpose: The Relevance of Masters Preparation for the Professional Practice of Nursing: A 10-Year Follow-up Study of Postgraduate Nursing Courses in the University of Edinburgh. Journal of Advanced Nursing. 2000; 31(5): 1072-1080. PMid:10840240 http://dx.doi.org/10.1046/j.1365-2648.2000.01388.x

[64] Drennan, J. Professional and Academic Destination of Masters in Nursing Graduates: A National Survey. Nurse Education Today. 2008; 28(6) p751-759. PMid:18242790 http://dx.doi.org/10.1016/j.nedt.2007.12.003

[65] Jordan, S. From Classroom Theory to Clinical Practice: Evaluating the Impact of a Post-registration Course. Nurse Education Today. 1998; 18(4): 293-302. http://dx.doi.org/10.1016/S0260-6917(98)80046-4

[66] Jordan, S. \& Hughes, D. Using Bioscience Knowledge in Nursing: Actions, Interactions, and Reactions. Journal of Advanced Nursing. 1998a; 27(5): 1060-1068. PMid:9637335 http://dx.doi.org/10.1046/j.1365-2648.1998.00611.x

[67] Jordan, S; Coleman, M; Hardy, B. \& Hughes, D. Assessing Educational Effectiveness: The Impact of a Specialist Course on the Delivery of Care. Journal of Advanced Nursing. 1990; 30(4): 796-807. PMid:10520091 http://dx.doi.org/10.1046/j.1365-2648.1999.01176.x

[68] Kenny, L. Education in Palliative Care: Making a Difference to Practice? International Journal of Palliative Nursing. 2001; 7(8): 401-407. PMid:11951785

[69] Rangeley, H. \& Arthurs, J. The Long-term Effects of Undertaking a Research Course on Clinical Practice. Nurse Education in Practice. 2004; 4(1): 12-19. http://dx.doi.org/10.1016/S1471-5953(03)00010-6

[70] Coughlan, M; Cronin, P. \& Ryan, F. Step-by-step Guide to Critiquing Research. Part 1: Quantitative Research. British Journal of Nursing. 2007; 16(11): 658-663. PMid:17577184

[71] National Institute for Health and Clinical Excellence. The Guidelines Manual. London: National Institute for Health and Clinical Excellence. 2009. Available from: https://www.nice.org.uk [date accessed: March 25th 2010]

[72] MacInnes, J. Mixed Methods Studies: A Guide to Critical Appraisal. British Journal of Cardiac Nursing. 2009; 4(12): 588-591.

[73] Teddie, C. \& Tashakkori, A. Foundations of Mixed Methods Research: Integrating Quantitative and Qualitative Approaches in the Social and Behavioural Sciences. Los Angeles, Sage Publications. 2009.

[74] Katrak, P; Bialocerkowski, A. E; Massy-Westropp, N; Kumar, S. \& Grimmer, K. A. A Systematic Review of the Content of Critical Appraisal Tools. http://dx.doi.org/10.1186/1471-2288-4-22 [on line]. BMC Medical Research Methodology. 2004 ; 4: 22. Available from: https://www.biomedcentral.com [date accessed: January 5th 2010]

[75] Humphreys, A, Johnson, S, Richardson, J, Stenhouse, E. \& Watkins, M. A Systematic review and Meta-synthesis: Evaluating the Effectiveness of Nurses, Midwife/Allied Health Professional Consultants. Journal of Clinical; Nursing. 2007; 16(10): 1792-1808. PMid:17880468 http://dx.doi.org/10.1111/j.1365-2702.2007.01757.x

[76] Sandelowski, M; Barroso, J. \& Voils, C. Using Qualitative Metasummary to Synthesis Qualitative and Quantitative Descriptive Findings. Research in Nursing and Health. 2007; 30(1): 99-111. http://dx.doi.org/10.1002/nur.20176

[77] Dixon-Woods, M; Shaw, R.L; Agarwal, S. \& Smith, J.A. The Problem of Appraising Qualitative Research. Quality and Safety in Health Care. 2004; 13(3): 223-225. PMid:15175495 http://dx.doi.org/10.1136/qshc.2003.008714

[78] Walsh, D. \& Downe, S. Meta-synthesis Method for Qualitative Research: A Literature Review. Journal of Advanced Nursing. 2005; 50(2): 204-211. PMid:15788085 http://dx.doi.org/10.1111/j.1365-2648.2005.03380.x 
[79] Pope, C. \& Mays, N. (eds). Ch. 13; Synthesising Qualitative Research in Qualitative Research in Health Care. Oxford, Blackwell Publishing. 2006.

[80] Popay, J, Roberts, H, Sowden, A, Petticrew, K, Arai, L, Rodgers, M, Britten, N, Roen, K. \& Duffy, S. Guidance on the Conduct of Narrative Synthesis in Systematic Reviews: A Product from the ESRC Methods Programme, Version 1 [Internet]. National Collaborating Centre for Methods and Tools. 2006. Available from: https://www.lancs.ac.uk/publications [date accessed January 5th 2010]

[81] Rodgers, M, Sowden, A, Petticrew, M, Arai, L, Roberts, H, Britten, N. \& Popay, J. Testing Methodological Guidance on the Conduct of Narrative Synthesis in Systematic Reviews: Effectiveness of Interventions to Promote Smoke Alarm Ownership and Function. Evaluation. 2009; 15(49): 49-74. http://dx.doi.org/10.1177/1356389008097871

[82] Lucas, P.J, Baird, J, Arai, L, Law, C. \& Roberts, H.M. Worked Examples of Alternative Methods for the Synthesis of Qualitative and Quantitative Research in Systematic Reviews [Internet]. BMC Medical Research Methodology. 2007. PMid:17224044 http://dx.doi.org/10.1186/1471-2288-7-4. Available from: https://www.biomedcentral.com [date accessed: April 21st 2010].

[83] Bradley, E, Curry, L. \& Devers, K. Qualitative Data Analysis for Health Services Research: Developing Taxonomy, Themes and Theory. Health Services Research. 2007; 42(2): 1758-1772. PMid:17286625 http://dx.doi.org/10.1111/j.1475-6773.2006.00684.x

[84] Braun, V. \& Clarke, V. Using Thematic Analysis in Psychology. Qualitative Research in Psychology. 2006; 3(2): 77-101. http://dx.doi.org/10.1191/1478088706qp063oa

[85] Finfgeld-Connett, D. Generalizability and Transferability of Meta-synthesis Research Findings. Journal of Advanced Nursing. 2010; 66(2): 246-254. PMid:20423407 http://dx.doi.org/10.1111/j.1365-2648.2009.05250.x

[86] Bowling, A. Research Methods in Health: Investigating Health and Health Services 3rd Ed. Maidenhead, Open University Press. 2009.

[87] Dale, A. Quality Issues with Survey Research. International Journal of Social Research Methodology. 2006; 9(2): 143-158. http://dx.doi.org/10.1080/13645570600595330

[88] Andrews, R. The Place of Systematic Reviews in Education Research. British Journal of Educational Studies. 2005; 53(4): 399-416. http://dx.doi.org/10.1111/j.1467-8527.2005.00303.x

[89] Weed, M. A Potential Method for the Interpretive Synthesis of Qualitative Research: Issues in the Development of "Meta-Interpretation. International Journal of Social Research Methodology. 2008; 11(1): 13-28.

http://dx.doi.org/10.1080/13645570701401222 